\title{
Gold Characterization of the San Luis Alta Mine, Ayacucho, Perú
}

\author{
Pura Alfonso' $^{1}$, Elsa Ccolqque ${ }^{1}$, Maite Garcia-Valles ${ }^{2}$, Maria Terersa Yubero ${ }^{1}$, Roger Gaona $^{1}$, Arnau \\ Martínez ${ }^{1}$ \\ ${ }^{1}$ Universitat Politècnica de Catalunya, Dept. d'Enginyeria Minera, Industrial i TIC \\ Av de les Bases de Manresa 61-73, 08242 Manresa, Spain \\ maria.pura.alfonso@upc.edu; elidaccf@gmail.com; rogergb8@hotmail.com; arnaumartalc@gmail.com \\ ${ }^{2}$ Universitat de Barcelona, Dept. de de Mineralogia, Petrologia i Geologia Aplicada \\ Carrer Martí i Franquès, s/n, 08028 Barcelona, Spain \\ maitegarciavalles@ub.edu
}

\section{Extended Abstract}

To obtain optimal results of a gold mining activity is essential to know the distribution of gold and its mineralogy. The San Luis Alta gold mine (Ayacucho, Peru) is an example of this. In this artisanal gold mine the ore is processed by cyanidation in the treatment plant. For an efficient process the reagent used will depend on how the gold is found [1]. The present work has been carried out to determine the gold characteristics to design an optimal processing of the materials from San Luis. The gold grades and the mineralogy of the veins and from several tailings produced along the exploitation history of this mine veins were determined.

The San Luis mine is located in the Arequipa segment of the Coastal Batholith, which is rich in hydrothermal gold deposits. The mineralization consists in veins hosted in diorites and granodiorites from the Tiabaya Super-Unit. This deposit belongs to the intrusive-related type [2]. Mineralization is mainly found in NW-SE in veins of some tens of decimetres wide and dipping about $70^{\circ}$. In other cases, the veins are sub-horizontal mantos. These veins are filled with quartz and abundant iron oxides. Locally, areas rich in minerals with $\mathrm{Cu}$-rich minerals are present, with alterations of malachite and azurite. Sulfides are mainly pyrite and minor chalcopyrite, sphalerite and galena.

Gold grades and tellurium content were analyzed. Mineralogy was studied with scanning electron microscopy and mineral chemistry was determined using an electron microprobe.

The gold content in the veins usually is between 40 and $60 \mathrm{~g} / \mathrm{t}$, but locally reach $121 \mathrm{~g} / \mathrm{t}$. the Te content vary between less than 10 and $180 \mathrm{~g} / \mathrm{t}$. Gold appears either in large grains, visible to the naked eye or, more frequently, in grains of less than $10 \mu \mathrm{m}$. Gold is encapsulated in Fe oxides, quartz and pyrite. There is a massive pyrite zone, which does not contain gold. Two different generations of gold minerals are distinguished in veins from the San Luis deposit. In the first generation, it occurs as native gold associated with pyrite. In the second generation, gold occurs as tellurides. The most abundant gold tellurides are petzite $\left(\mathrm{Ag}_{3} \mathrm{AuTe}_{2}\right)$ and calaverite $\left(\mathrm{AuTe}_{2}\right)$ Other tellurides present are silvanite $\left((\mathrm{Ag}, \mathrm{Au})_{2} \mathrm{Te}_{4}\right)$, hessite $\left(\mathrm{Ag}_{2} \mathrm{Te}\right)$ and kawazulite $\left(\mathrm{Bi}_{2}(\mathrm{Te}, \mathrm{Se}, \mathrm{S})_{3}\right)$.

The process carried out consists of cyanidation after oxidation in an alkaline environment. Cement is added to maintain a high $\mathrm{pH}$. This processing allows a relatively high recovery. After the treatment the tailings contain less than $1 \mathrm{~g} / \mathrm{t} \mathrm{Au}$. The old tailings heaps from the mercury amalgamation treatment that was previously carried out contain more than $40 \mathrm{~g} / \mathrm{t} \mathrm{Au}$.

\section{References}

[1] L. Lorenzen, J.S. Deventer and W.M. Landi, "Factors affecting the mechanism of the adsorption of arsenic species on activated carbon," Minerals Eng., vol. 8, pp 557-569, 1995.

[2] P. Alfonso, H. Anticoi, T. Yubero, M. Bascompta., L. Henao, M. Garcia-Valles, S. Palacios and J. Yáñez "The importance of mineralogical knowledge in the sustainability of artisanal gold mining: A mid-south Perú case," Minerals, vol. 9, no 6, p. 345, 2019. 